\section{NưN Kastamonu Eğitim Dergisi Kastamonu Education Journal}

Eylül 2019 Cilt:27 Sayı:5

kefdergi.kastamonu.edu.tr
Başvuru Tarihi/Received: 11.10.2018

Kabul Tarihi/Accepted: 11.01.2019

DOI: $10.24106 /$ kefdergi.3387

\title{
Okul Öncesi Öğretmenlerinin STEM Semantik Algılarının ve STEM Yaklaşımına Yönelik Düşüncelerinin Belirlenmesi'
}

\section{Determination of STEM Semantic Perceptions and Thoughts for the Approach of STEM of the Pre-School Teachers}

\section{Öz}

\author{
Gülşah GÜNŞEN², Gülden UYANIK ${ }^{3}$, Berrin AKMAN ${ }^{4}$
}

STEM yaklaşımı ile çocukların fen ve matematik gibi temel bilimlerin ortaya koyduğu kuramsal bilgileri alıp teknoloji ve mühendisliği harmanlayarak yaşama değer katacak yenilikler yapması beklenmektedir. Bu noktada STEM yaklaşımının okul öncesi öğretmenleri tarafindan doğru algılanması ve doğru uygulamalarla okul öncesi dönem çocuklarına uygulanması önem arz etmektedir. Yapılan bu araştırmanın amacı okul öncesi öğretmenlerinin STEM yaklaşımına yönelik düşüncelerinin ve STEM semantik algılarının belirlenmesidir. Karma araştırma yöntemi kullanılarak yapılan araştırmanın çalışma grubunu MEB bağıı bağımsız anaokullarındaki 30 okul öncesi öğretmeni oluşturmaktadır. Okul öncesi öğretmenlerinin STEM yaklaşımına yönelik düşünceleri araştırmacılar tarafindan geliştirilen görüşme formu ile STEM alanlarına yönelik algıları ise Knezek ve Christensen (2008) tarafindan geliştirilen Türkçe'ye uyarlaması Kızılay (2017) tarafindan yapılan STEM Semantik Farklılık Ölçeği kullanılarak belirlenmiştir. Yapılan bu araştırmadan elde edilen bulgular doğrultusunda genel olarak okul öncesi öğretmenlerinin STEM alanlarına yönelik anlamsal algılarının olumlu tutumlar içerdiği, STEM yaklaşımına yönelik çok az fikre sahip oldukları ve okul öncesi dönemde STEM yaklaşımının uygulanma gerekçesi olarak en çok çocukların erken dönemde bilimle tanışması, yaratıcılığının gelişmesine destek sunması, problem çözme becerisinin gelişimini sağlaması düşüncelerine sahip oldukları tespit edilmiştir.

Anahtar Kelimeler: STEM yaklaşımı, STEM alanları, okul öncesi öğretmenleri, semantik algı

\section{Abstract}

The STEM approach is expected to bring innovations that add value to life by blending technology and engineering with the theoretical knowledge presented by basic sciences such as science and mathematics. At this point, it is important that the STEM approach is perceived correctly by preschool teachers and applied to preschool children with correct practices. The aim of this research is to determine the thoughts of pre-school teachers about STEM approach and the semantic perceptions of STEM. The study group of the research using mixed research method consists of 30 preschool teachers in independent kindergartens. The thoughts of pre-school teachers about STEM approach were determined by the interview form developed by the researchers. STEM semantic perceptions of preschool teachers were determined by using STEM Semantic Differential Scale which was developed by Knezek and Christensen (2008) and adapted to Turkish by Kızılay (2017). According to the results, the semantic perceptions of pre-school teachers about STEM areas in general have positive attitudes towards STEM areas, they have very little idea for STEM approach and the reason for application of STEM approach in preschool period is that children are introduced to science in the early period and they support the development of creativity. It is seen that they have the idea to provide the development of problem-solving skills.

Keywords: STEM approach, STEM fields, pre-school teachers, semantic perception

1. Bu araştırma 6. Uluslararası Öğretim Teknolojileri ve Öğretmen Eğitimi Kongresi'nde sözel bildiri olarak sunulmuştur.

2. Trakya Üniversitesi Eğitim Fakültesi, Temel Eğitim Bölümü, Edirne, Türkiye; https://orcid.org/0000-0002-6882-5645

3. Marmara Üniversitesi Atatürk Eğitim Fakültesi, Temel Eğitim Bölümü,İstanbul, Türkiye; https://orcid.org/ 0000-0001-9947-8159.

4. Hacettepe Üniversitesi, Eğitim Fakültesi, Ankara,Türkiye; https://orcid.org/0000-0001-5668-4382.

Atıf / Citation: Günşen, G., Uyanık, G. \& Akman, B. (2019). Okul Öncesi Öğretmenlerinin STEM Semantik Algılarının ve STEM Yaklaşımına Yönelik Düşüncelerinin Belirlenmesi. Kastamonu Education Journal, 27(5), 2173-2186. doi:10.24106/kefdergi.3387 


\section{Extended Summary}

Science, technology, engineering and mathematics can be seen as imaginary areas for preschool children, but in reality, preschool children can spontaneously carry out STEM activities in the classroom, on the playground, at home, at the market, and so on. they perform regularly in many places. At this point, the importance of integrating the STEM approach in children's life from the early years into the education process is a critical point for the STEM approach to be understood by preschool teachers and planning the educational process by taking advantage of young children's interest, experience and preliminary knowledge. With the STEM approach, it is expected that children will take the theoretical knowledge revealed by the basic sciences such as science and mathematics and blend the technology and engineering and make innovations that add value to life. However, this may depend on the correct perception of the STEM approach by preschool teachers and their application to pre-school children. However, it is observed that the applications for pre-school children are not enough.

In this research, the descriptive survey was structured according to the survey model and mixed research method was used. The study group consists of 30 preschool teachers in independent kindergartens affiliated to Ministry of National Education. If the demographic characteristics of the pre-school teachers participating in the study are summarized, it is observed that they are generally women-majority, 20-30 years of age undergraduate and have 1-5 years of professional experience. Quantitative and qualitative measurement tools were used in the study. The semantic perceptions of pre-school teachers for STEM areas were determined by STEM Semantic Differences Scale and their thoughts about STEM approach were determined by the interview form prepared by the researchers. The STEM Semantic Differential Scale developed by Knezek and Christen (2008) and adapted to Turkish by Kızılay (2017) was used to determine the semantic perceptions of pre-school teachers for STEM. In order to determine the thoughts of preschool teachers about STEM approach, while creating questions of Preschool Teachers' opinions on STEM approach, many of the studies which are similar to this topic have been examined (Park, Dimitrov, Patterson ve Park, 2017; Gerde, Steven, Pierce, Kyungsook Lee ve Van Egeren, 2017; Wang, Moore, Roehrig ve Park, 2011; Corlu, Capraro ve Capraro, 2014). Using the questions in the literature, the final form was obtained by taking the expert opinion for the interview form prepared according to the open-ended and closed-ended questions determined by the researchers. Although the open-ended questions of the interview form were asked about the importance of STEM approach in teachers and their importance in pre-school education, in closed-ended questions, preschool teachers rate themselves according to their attitudes towards STEM approach.

When the results of the study are examined, it is seen that the semantic perceptions of pre-school teachers about STEM areas in general have positive attitudes, they have very little idea about STEM approach, and they are the reason for application of STEM approach in preschool period. It is seen that they have the idea to ensure the development of their skills. According to the findings obtained from the STEM Semantic Differences Scale used to determine the semantic perceptions of pre-school teachers towards STEM areas, pre-school teachers have positive attitudes towards science and have many meanings for them in science ( $\bar{X}=6.3$, and interesting for themselves ([?]=5.9; SS: 1.14 ).

When the semantic perception of pre-school teachers towards mathematics is examined, it is seen that they perceive the mathematics field as impressive for themselves ( $\bar{X}=5.7$; SS: 1.6$)$ and that they perceive them as attractive $(\bar{X}=5.5 ;$ SS: 1.3$)$. When the semantic perceptions of pre-school teachers in engineering field are examined, it is seen that the engineering field is exciting for them $(\bar{X}=4.0$; SS: 1.9) and they have many meanings for themselves $(\bar{X}=3.4 ;$ SS: 1.7$)$. When the semantic perceptions of pre-school teachers towards technology are examined, it is seen that the technology field is impressive for them $(\bar{X}=$ 6.2; SS: 1.4$)$ and they have positive expressions for themselves $(\bar{X}=6.2$; SS: 1.6$)$.

When the opinions of preschool teachers about STEM approach are examined, it is seen that teachers do not have a ge-

neral knowledge about STEM approach and they do not express their opinions. The pre-school teachers who expressed their opinions stated that STEM approach consists of robotic applications in general, supports creativity and technology learning in children, it is a way of conducting experiments in children, provides support for the development of scientific process skills, provides opportunities for making designs with legos and also problem solving from 21st century skills skills, they think that

they offer support for critical thinking skills. Although there are only 2 preschool teachers who have received training on STEM approach among the participants of the study, although they do not have knowledge of the STEM approach in general, they may have negative opinions about their application at an early age, even though they do not trust themselves and do not know how to apply the approach. The fact that they stated that they would like to apply STEM approach in the classroom reveals the need for STEM approach to be learned by preschool teacher by increasing the number of trainings for STEM approach to preschool teachers who are eager for science teaching in the early period.

In today's children's struggle to survive in the future to develop new inventions STEM (Science, Technology, Engineering, Mathematics) passes the training. Research indicates that in the next 10 years, $80 \%$ of occupations will require a deep understanding of STEM skills. For this reason, STEM education should be started from preschool period and the education of science, mathematics, engineering and technology should be given to the children by spreading the necessary teacher training and organizing the appropriate learning environments In addition, the addition of the STEM approach and its applications to the undergraduate program is considered to be a necessity today for educating teachers and children in accordance with the requirements of the 21st century. 


\section{Giriş}

Fen, teknoloji, mühendislik ve matematik okul öncesi dönem çocukları için hayalî alanlar olarak görülebilir ancak gerçekte, okul öncesi dönem çocukları bu alanlara yönelik STEM faaliyetlerini sınıf içinde, oyun alanında, evde, markette vb. birçok yerde düzenli olarak yürütürler (Günşen ve Uyanık Balat, 2017). Bu noktada doğal olarak çocukların yaşamında yer alan STEM yaklaşımının erken dönemden itibaren eğitim sürecine entegre edilmesinin önemi (Chesloff, 2013; Katz, 2010) düşünülecek olursa okul öncesi öğretmenleri tarafindan STEM yaklaşımının doğru anlaşılması ve eğitim sürecinin küçük çocukların ilgi, deneyim ve ön bilgisinden yararlanarak planlanması kritik noktayı oluşturur (NRC, 2011). Özellikle eğitim ortamında sorgulayıcı yaklaşımı benimsemiş bir okul öncesi öğretmeni çocukların bilimle anlamlı şekilde tanışmasına ve sevmesine firsat sağlamaktadır (Leuchter, Saalbach ve Hardy, 2014; Furtak, Seidel, Iverson ve Briggs, 2012; Trundle ve Saçkes, 2012). Okul öncesi dönemde çocuklara STEM alanına yönelik bilgi ve becerilerini kazandırabilmek için iyi hazırlanmış bir eğitim programı ve alanına hâkim okul öncesi öğretmenleri önem arz etmektedir. Eğer okul öncesi dönem çocuğuna STEM yaklaşımına uygun etkinliklerin yer aldığı bir müfredat iyi yetişmiş okul öncesi öğretmenleri tarafindan uygulanırsa ancak o zaman okul öncesi çocukları etkin bir şekilde STEM yaklaşımı ile tanışır ve bu alanlara yönelik bilgi ve becerilerini geliştirebilir (Clements, 2013; NAEYC, 2009).

STEM yaklaşımı ile çocukların fen ve matematik gibi temel bilimlerin ortaya koyduğu kuramsal bilgileri alıp teknoloji ve mühendisliği harmanlayarak yaşama değer katacak yenilikler yapması beklenmektedir (Hobbs, Clark ve Plant, 2018; Akgündüz, Aydeniz, Çakmakçı, Çavaş, Çorlu, Öner ve Özdemir, 2015). Bu süreç özellikle okul öncesi dönem açısından değerlendirilecek olursa okul öncesi dönemde STEM yaklaşımına dayalı etkinliklerle çocuklar etrafindaki dünyayı keşfedebilmekte (NSTA, 2011) ve fen, teknoloji, mühendislik ve matematik alanlarına yönelik temel kavramları kazanabilmekte (Gonzales ve Freyer, 2014) ve ayrıca sosyal gelişimleri, dil gelişimleri ve okula hazır bulunuşlukları da desteklenebilmektedir (Clements ve Sarama, 2016; Sullivan ve Bers, 2016). Bu noktada özellikle okul öncesi dönemde STEM yaklaşımının okul öncesi öğretmenleri tarafindan doğru algılanması ve doğru uygulamalarla okul öncesi dönem çocuklarına uygulanması önem arz etmektedir. Yerli ve yabancı alan yazın incelendiğinde birçok araştırmacı STEM konusunu çalışmakta ve bu alanda makale, bildiri, rapor yazmaktadır. Ancak yapılan çalışmaların hedef kitlesinin hem yurt içinde hem de yurt dışında çoğunlukla ilk, orta okul ve üst kademedeki çocuklar olduğu görülmektedir (Akgündüz ve Özçelik, 2018; Awad ve Barak, 2018; Beymer, Rosenberg ve Schmidt, 2018; Çevik, 2018; Ensari, 2017; Gökbayrak ve Karışan, 2017; Pekbay, 2017; Selvi ve Yıldırım, 2017; Akdağ ve Güneş, 2015; Becker ve Park, 2011; Bybee, 2010). Okul öncesi dönem çocuklarına yönelik uygulamaların ise yeterli oranda olmadığı görülmektedir (Akgündüz ve Akpınar, 2018; Safiee, Jusoh, Noor, Tek ve Salleh, 2018; Alade, Lauricella, Beaudoin ve Watella, 2016; Aldemir ve Kermani, 2016; Milford ve Tippet, 2016; Aronin ve Floyd, 2013; Brenneman, 2011; Moomaw ve Davis, 2010). Oysaki okul öncesi dönemde çocuklar fen, teknoloji, matematik, mühendislik, bilimsel kavramlar dâhil birçok kavramı kazanmaya başlar. Çocuklara bu kavramlar kazandırılırken; yeni edindikleri kavramları uygulamalarını, kendilerinde var olan kavramlarla birleştirerek genişletmelerini ve yeni kavramları kendilerinin yapılandırarak öğrenmelerini sağlayacak etkinliklere ve ortamlara gereksinim duyulur. Çocukların STEM alanlarını bütünleştirerek bilim öğrenmelerinin sağlanması da bu çağın gereği olarak önemlidir (Akgündüz ve Akpınar, 2018; Uyanık Balat ve Günşen, 2017). Alan yazında okul öncesi dönemde STEM yaklaşımına yönelik olarak yapılan araştırmalar incelendiğinde araştırmaların genel olarak STEM yaklaşımının okul öncesi dönemde kullanılmasının çocuğun gelişimine katkıları şeklinde olduğu (Beymer, Rosenberg, Schmidt ve Naftzger, 2018; Uyanık Balat ve Günşen, 2017; Chesloff, 2013; Becker ve Park, 2011; Moomaw ve Davis, 2010), çok az araştırmanın STEM yaklaşımına yönelik olarak hazırlanan etkinliklerin deneysel olarak uygulanmasının çocuklar üzerindeki etkilerini ortaya koymaya yönelik olduğu (Awad ve Barak, 2018; Günşen, Fazlıoğlu ve Bayır, 2017; Aldemir ve Kermani, 2016; Aronin ve Floyd, 2013) görülmektedir.

Okul öncesi öğretmenlerinin STEM yaklaşımına yönelik görüşlerinin alındığı (Park, Dimitrov, Patterson ve Park, 2017; Uğraş, 2017) ve aynı zamanda STEM alanlarına yönelik algılarının neler olduğunun belirlendiği araştırmalara yeterli düzeyde ulaşılamamıştr. Özellikle Park, Dimitrov, Patterson ve Park (2017) tarafindan yapılan çalışmada, okul öncesi öğretmenlerinin STEM yaklaşımının erken dönemden itibaren uygulanmasının önemli olduğunu ifade ettikleri ancak kendilerini bu konuda yetersiz gördükleri ve STEM yaklaşımını kullanarak sınıf içi etkinlikler düzenleme konusunda desteğe ihtiyaç duydukları tespit edilmiştir. Bu noktada ülkemizdeki okul öncesi öğretmenlerinin STEM yaklaşımına yönelik düşüncelerinin ve STEM alanlarına yönelik anlamsal algılarının belirlenmesinin okul öncesi dönemde STEM yaklaşımı uygulamalarının ne derecede başarılı olabileceğine ve ne şekilde düzenlemeler yapılabileceğine ışık tutacağı düşünülmektedir.

Bu noktadan hareketle yapılan bu araştırmanın temel amacı okul öncesi öğretmenlerinin STEM yaklaşımına yönelik düşüncelerinin ve STEM alanlarına yönelik anlamsal algılarının belirlenmesidir. 


\section{Yöntem}

Bu araştırma, betimsel türde tarama (survey) modeline göre yapılandırılmış ve karma araştırma yöntemi kullanılmıştır. Karma araştırma yöntemi araştırmacıların konuyu derinlemesine inceleyebilmesi amacıyla nitel ve nicel araştırma yöntemlerini bir arada kullandıkları bir araştırma türüdür (Johnson, Onwuegbuzie ve Turner, 2007). Araştrmanın deseni olarak da yakınsayan paralel desen kullanılmıştı (Creswell ve Clark, 2015). Yakınsayan paralel desen nitel ve nicel araştırma sürecinin eş zamanlı olarak uygulanmasıyla oluşur. Bu desen yöntemlere eşit öncelik verir, çözümleme sırasında bu aşamaları birbirinden ayrı tutar ve daha sonra genel yorumlama yaparken sonuçları birleştirir (Creswell ve Clark, 2015). Yapılan bu araştırmada da nicel ve nitel verilerin toplanma süreci eş zamanlı yürütülmüş olup, çözümleme sırasında nicel ve nitel veriler ayrı olarak analiz edilmiş ve sonra birlikte yorumlanmıştır.

\section{Çalıșma Grubu}

Karma araştırma yöntemi kullanılarak yapılan araştırmanın çalışma grubunu Edirne il merkezinde görevli MEB bağı bağımsız anaokullarındaki 30 okul öncesi öğretmeni oluşturmaktadır (Büyüköztürk, 2012). Araştırmanın çalışma grubunun belirlenmesinde kolay ulaşım sağlanabilmesi amacıyla olasılıklı olmayan örnekleme tekniklerinden kolay ulaşılabilir örnekleme kullanılmıştır (Gürbüz ve Şahin, 2016). Araştırmanın katılımcılarının demografik özellikleri Şekil 1'de gösterilmektedir.

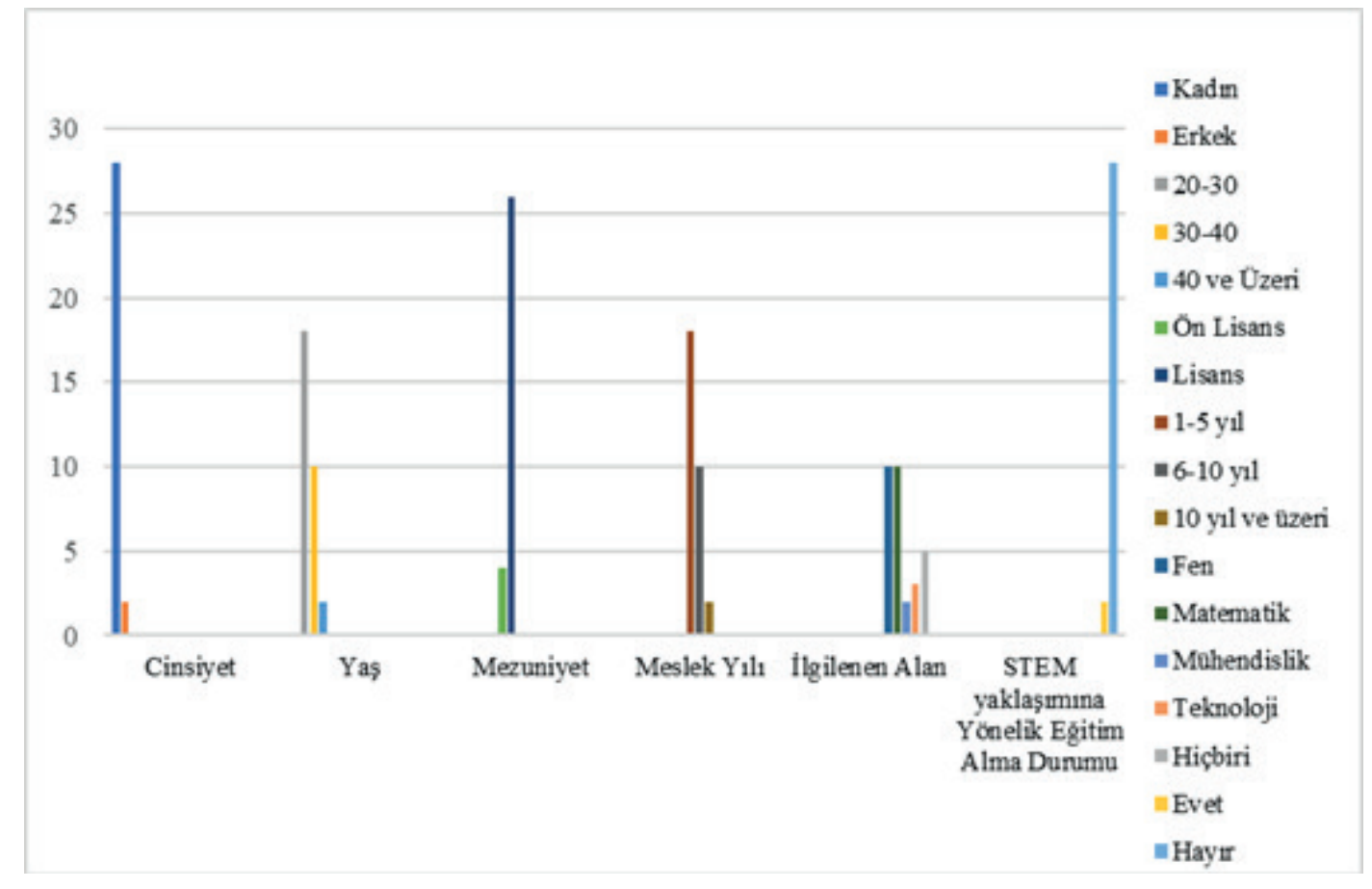

\section{Şekil 1: Okul öncesi öğretmenlerinin demografik özellikleri}

Araştırmanın katılımcılarının demografik özellikleri incelendiğinde araştırmada yer alan okul öncesi öğretmenlerinin \%93.3'ünün ( $n=28)$ kadın, \% 6.67'sinin $(n=2)$ erkek, \%60'ının $(n=18)$ 20-30 yaş aralığında \%33.3'ünün $(n=10)$ 30-40 yaş aralığında ve \% 6.66'sının $(n=2) 40$ yaş üzeri olduğu görülmektedir. Okul öncesi öğretmenlerinin \%13.3'ünün $(n=4)$ ön lisans mezunu, \% 86.7'sinin ( $n=26)$ lisans mezunu olduğu ve meslek yılı olarak \%60'ının $(n=18)$ 1-5 yıllık mesleki deneyime, \%33.3'ünün ( $n=10) 6$-10 yıllık deneyime, ve \%6.66'sının $(n=2) 10$ yıl üzeri mesleki deneyime sahip oldukları görülmektedir. Okul öncesi öğretmenlerinin ilgilendikleri bilim alanlarına yönelik ise öğretmenlerin \%33.3'ünün ( $n=10)$ fen alanı ile, \%33.3'ünün (10 kişi) matematik alanı ile, \%10'unun $(n=3)$ teknoloji alanı ile ve \% 23.3'ünün ( $n=7)$ hiçbir bilimsel alana ilgi duymadığını ifade ettiği görülmektedir. Okul öncesi öğretmenlerinin önceden STEM yaklaşımına yönelik herhangi bir eğitim alıp almama durumuna bakıldığında ise okul öncesi öğretmenlerinin \%93.3'ünün ( $n=28)$ STEM yaklaşımına yönelik her hangi bir eğitim almadığı, \% 6.67'sinin (2 kişi) ise STEM yaklaşımına yönelik bir eğitime (çeşitli üniversiteler ve kurumlar tarafindan verilen STEM eğitim kursları) katıldığını ifade ettiği görülmektedir.

Araştırmaya katılan okul öncesi öğretmenlerinin demografik özellikleri özetlenecek olursa genel olarak kadın çoğunluklu, 20-30 yaş aralığında lisans mezunu ve 1-5 yıllık mesleki deneyime sahip oldukları görülmekle birlikte çoğunlukla fen ve matematik alanlarına ilgili oldukları ve STEM yaklaşımına yönelik bir eğitim almadıkları görülmektedir. 


\section{Veri Toplama Araçları}

Araştırmanın genel amacı okul öncesi öğretmenlerinin STEM yaklaşımına yönelik düşüncelerinin ve STEM alanlarına yönelik anlamsal algılarının belirlenmesidir. Bu amaç doğrultusunda araştırma kapsamında nicel ve nitel ölçüm araçları kullanılmıştır. Okul öncesi öğretmenlerinin STEM alanlarına yönelik anlamsal algıları STEM Semantik Farklılık Ölçeği ile STEM yaklaşımına yönelik düşünceleri ise araştırmacılar tarafindan hazırlanmış olan görüşme formu ile belirlenmiştir.

\section{STEM Semantik Farklıık Ölçeği}

Okul öncesi öğretmenlerinin STEM alanlarına yönelik anlamsal algılarını belirlemede kullanılabilmek amacıyla Knezek ve Christen (2008) tarafindan geliştirilen ve Kızılay (2017) tarafindan Türkçe 'ye uyarlanan STEM Semantik Farklılık Ölçeği kullanılmıştır. Ölçek 5 alt boyuttan (fen, matematik, mühendislik, teknoloji ve kariyer) oluşmakta olup, ölçeğin uyarlama çalışması fen bilgisi öğretmenliği ve ilköğretim matematik öğretmenliği adayları ile yapılmıştr. Ölçeğin bütünü için cronbach alpha güvenirlik katsayısı .82 olarak hesaplanmış olup, bu araştırma için güvenirlik katsayısı ise .83 olarak hesaplanmıştır.

Okul öncesi öğretmenlerinin STEM alanlarına yönelik anlamsal algılarını belirlemek amacıyla kullanılan STEM Semantik Farklılık ölçeğinin değerlendirilmesi şu şekildedir.

STEM semantik farklılık ölçeğinde olumlu maddelerde en yüksek puan 7, en düşük puan 1 olacak şekilde puanlama yapılmaktadır. Buna göre örneğin katlımcı;

Benim için Matematik:

$\begin{array}{llllllll} & 1 & 2 & 3 & 4 & 5 & 6 & 7 \\ \text { 1.Etkileyici } & & & & & & & (\mathrm{X})\end{array}$

Maddesi için 6 puanı işaretlediyse 6 puan yazılmaktadır. Çünkü bu madde olumlu bir maddedir. Ancak;

\section{Benim için Fen:}

$\begin{array}{llllllll} & 1 & 2 & 3 & 4 & 5 & 6 & 7 \\ 1 . \text { SIkıcI } & & & & & & & \end{array}$

(X)

Maddesi için 6 puan işaretlediyse 2 puan yazılmakta, çünkü bu madde olumsuz bir maddedir.

\section{Okul Öncesi Öğretmenlerinin STEM Yaklaşımına Yönelik Düşüncelerini Belirleyici Görüşme Formu}

Okul öncesi öğretmenlerinin STEM yaklaşımına yönelik düşüncelerini belirlemek amacıyla araştırmacılar tarafindan geliştirilen Okul Öncesi Öğretmenlerinin STEM Yaklaşımına Yönelik Düşüncelerini Belirleyici Görüşme Formu soruları oluşturulurken alan yazında bu konuya benzer olarak yapılmış birçok çalışma incelenmiştir (Park, Dimitrov, Patterson ve Park, 2017; Gerde, Steven, Pierce, Kyungsook Lee ve Van Egeren, 2017; Wang, Moore, Roehrig ve Park, 2011; Corlu, Capraro ve Capraro, 2014). Alan yazındaki sorulardan yararlanılarak araştırmacılar tarafindan belirlenen açık uçlu ve kapalı uçlu sorular doğrultusunda hazırlanan görüşme formu için uzman görüşü alınmış ve son hali verilmiştir. Görüşme formunun açık uçlu sorularında öğretmenlere "STEM yaklaşımının ne olduğu" ve "okul öncesi eğitimdeki öneminin ne olabileceği" sorulmuştur. Elde edilen veriler içerik analizi yöntemi kullanılarak analiz edilmiştir (Schreier, 2014). İçerik analizinde, güvenirliğin belirlenmesi amacıyla 2 uzman görüşü alınarak uyuşum yüzdesi formülü olan "güvenirlik = ortak görüş/ (ortak görüş + görüş farklılı̆ıı) x 100" kullanılarak hesaplanmıştır (Miles ve Huberman, 1994). Araştirmada, bu formül kullanılarak uyuşum yüzdesi 0,90 olarak hesaplanmış olup bu değer \%70' in üstü olduğu için yapılan içerik analizinin güvenilir olduğu belirlenmiştir (Yıldırım ve Şimşek, 2003).

Görüşme formunun kapalı uçlu sorularında ise okul öncesi öğretmenleri kendilerini; "STEM yaklaşımını uygulamaktan hoşlanma durumuna", "STEM yaklaşımını uygulamayı bilme durumuna","STEM yaklaşımını uygulamada kendine güvenme durumuna", "STEM yaklaşımı uygulaması için gerekli yöntem ve teknikleri bilme durumuna", "STEM yaklaşımını uygulamak için yeterli bilimsel bilgiye sahip olup olmama durumlarına" göre kesinlikle katılıyorum, katılıyorum, kararsızım, katılmıyorum, kesinlikle katılmıyorum şeklinde değerlendirmiştir. 


\section{Bulgular}

\section{STEM Semantik Farklılık Ölçeği'nden elde edilen bulgular}

Okul öncesi öğretmenlerinin STEM alanlarına yönelik anlamsal algılarını belirlemek amacıyla STEM Semantik Farklılık Ölçeği kullanılmıştır. Okul öncesi öğretmenlerinin STEM semantik farklıık ölçeğinin fen alanına yönelik anlamsal algıları Tablo 1'de yer almaktadır.

Tablo 1. Okul öncesi öğretmenlerinin STEM semantik farklılık ölçeğinin fen alanına yönelik anlamsal algıları

\begin{tabular}{|c|c|c|c|c|c|c|c|c|c|c|c|c|c|c|c|c|c|}
\hline Fen Alanı & & & & & & & & & & & & & & & & & \\
\hline \multirow{3}{*}{ Semantik ifadeler } & \multirow{3}{*}{$\mathbf{N}$} & \multirow{3}{*}{$\bar{x}$} & \multirow{3}{*}{ SS } & \multicolumn{14}{|c|}{ Semantik ifadelerin Dereceleri } \\
\hline & & & & \multicolumn{2}{|c|}{7} & \multicolumn{2}{|c|}{6} & \multicolumn{2}{|c|}{5} & \multicolumn{2}{|c|}{4} & \multicolumn{2}{|c|}{3} & \multicolumn{2}{|c|}{2} & \multicolumn{2}{|c|}{1} \\
\hline & & & & f & $\%$ & $f$ & $\%$ & $f$ & $\%$ & $f$ & $\%$ & $f$ & $\%$ & $f$ & $\%$ & f & $\%$ \\
\hline Etkileyici-Sıradan & 30 & 5.4 & 1.01 & 4 & 13.3 & 14 & 46.7 & 4 & 13.3 & 6 & 20 & 2 & 6.7 & - & - & - & - \\
\hline Cazip-Cazip Değil & 30 & 5.4 & 1.11 & 6 & 20.0 & 8 & 26.7 & 9 & 20.0 & 7 & 23.3 & - & - & - & - & - & - \\
\hline Heyecan Verici-Heyecansız & 30 & 5.4 & 1.06 & 5 & 16.7 & 13 & 43.3 & 4 & 13.3 & 5 & 16.7 & 3 & 10.0 & - & - & - & - \\
\hline $\begin{array}{l}\text { Birçok Anlamı Var-Hiçbir } \\
\text { Anlamı Yok }\end{array}$ & 30 & 6.3 & 1.08 & 18 & 60.0 & 6 & 20.0 & 2 & 6.7 & 4 & 13.3 & - & - & - & - & - & - \\
\hline İlginç-Sıkıcı & 30 & 5.9 & 1.14 & 12 & 40.0 & 7 & 23.3 & 6 & 20.0 & 5 & 16.7 & - & - & - & - & - & - \\
\hline
\end{tabular}

Tablo 1'de okul öncesi öğretmenlerinin fen alanına yönelik anlamsal algıları incelendiğinde belirlenen aritmetik ortalama değerlerine göre fen alanına yönelik anlamsal algılarından etkileyici-sıradan semantik ifadesi için $(\bar{X}=5.4$; SS:1.01), cazip-cazip değil semantik ifadesi için ( $\bar{X}=5.4 ;$ SS: 1.11), heyecan verici-heyecansız semantik ifadesi için $(\bar{X}=5.4$; SS: 1.06), birçok anlamı var- hiçbir anlamı yok semantik ifadesi için ( $\bar{X}=6.3$; SS: 1.08), ilginç- sıkıcı semantik ifadesi için $(\bar{X}=5.9 ;$ SS: 1.14) olduğu görülmektedir. Buna göre aritmetik ortalama değerlerinden anlaşılacağı üzere okul öncesi öğretmenlerinin fen alanını en çok birçok anlamı var olarak ve ilginç olarak algılamaktadır.

Okul öncesi öğretmenlerinin STEM semantik farklılık ölçeğinin matematik alanına yönelik anlamsal algıları Tablo 2'de yer almaktadır.

Tablo 2. Okul öncesi öğretmenlerinin matematik alanına yönelik anlamsal algıları

\begin{tabular}{|c|c|c|c|c|c|c|c|c|c|c|c|c|c|c|c|c|c|}
\hline \multicolumn{18}{|l|}{ Matematik Alanı } \\
\hline \multirow{3}{*}{ Semantik ifadeler } & \multirow{3}{*}{$\mathbf{N}$} & \multirow{3}{*}{$\bar{x}$} & \multirow{3}{*}{ SS } & \multicolumn{14}{|c|}{ Semantik ifadelerin Dereceleri } \\
\hline & & & & \multicolumn{2}{|c|}{7} & \multicolumn{2}{|c|}{6} & \multicolumn{2}{|c|}{5} & \multicolumn{2}{|c|}{4} & \multicolumn{2}{|c|}{3} & \multicolumn{2}{|c|}{2} & \multicolumn{2}{|c|}{1} \\
\hline & & & & $f$ & $\%$ & $f$ & $\%$ & $f$ & $\%$ & $f$ & $\%$ & $f$ & $\%$ & $f$ & $\%$ & $f$ & $\%$ \\
\hline İlginç-Sıkıcı & 30 & 4.9 & 1.9 & 8 & 26.7 & 4 & 13.3 & 7 & 23.3 & 5 & 16.7 & 2 & 6.7 & 2 & 6.7 & 2 & 6.7 \\
\hline Cazip-Cazip Değil & 30 & 5.5 & 1.3 & 10 & 33.3 & 8 & 26.7 & 2 & 6.7 & 8 & 26.7 & - & - & 2 & 6.7 & - & - \\
\hline Etkileyici-Sıradan: & 30 & 5.7 & 1.6 & 8 & 26.7 & 8 & 26.7 & 10 & 33.3 & 2 & 6.7 & - & - & 4 & 13.3 & - & - \\
\hline Heyecan verici-Heyecansız & 30 & 5.2 & 1.8 & 10 & 33.3 & 4 & 13.3 & 7 & 23.3 & 5 & 16.7 & - & - & 2 & 6.7 & 2 & 6.7 \\
\hline $\begin{array}{l}\text { Birçok anlamı var-Hiçbir } \\
\text { anlamı yok- }\end{array}$ & 30 & 5.2 & 1.7 & 10 & 33.3 & 4 & 13.3 & 5 & 16.7 & 7 & 23.3 & - & - & 4 & 13.3 & - & - \\
\hline
\end{tabular}

Tablo 2 incelendiğinde okul öncesi öğretmenlerinin matematik alanına yönelik anlamsal algıları incelendiğinde belirlenen aritmetik ortalama değerlerine göre matematik alanına yönelik anlamsal algılarından ilginç-sıkıcı semantik ifadesi için ( $\bar{X}=4,9 ;$ SS:1.9), cazip-cazip değil semantik ifadesi için ( $\bar{X}=5.5 ;$ SS: 1.3$)$, etkileyici-sıradan semantik ifadesi için $(\bar{X}=5.7 ;$ SS: 1.6$)$, heyecan verici-heyecansız semantik ifadesi için $(\bar{X}=5.2 ;$ SS: 1.8$)$, bir çok anlamı var- hiçbir anlamı yok 
semantik ifadesi için $(\bar{X}=5.2 ;$ SS: 1.7) olduğu görülmektedir. Buna göre aritmetik ortalama değerlerinden anlaşılacağı üzere okul öncesi öğretmenlerinin matematik alanını en çok etkileyici olarak ve cazip olarak algılamaktadır.

Okul öncesi öğretmenlerinin STEM semantik farklılı ölçeğinin mühendislik alanına yönelik anlamsal algıları Tablo 3'de yer almaktadır.

Tablo 3. Okul Öncesi Öğretmenlerinin Mühendislik Alanına Yönelik Anlamsal Algıları

\begin{tabular}{|c|c|c|c|c|c|c|c|c|c|c|c|c|c|c|c|c|c|}
\hline \multicolumn{18}{|l|}{ Mühendislik Alanı } \\
\hline \multirow{3}{*}{ Semantik Ifadeler } & \multirow{3}{*}{$\mathrm{N}$} & \multirow{3}{*}{$\bar{x}$} & \multirow{3}{*}{ SS } & \multicolumn{14}{|c|}{ Semantik Ifadelerin Dereceleri } \\
\hline & & & & \multicolumn{2}{|c|}{7} & \multicolumn{2}{|c|}{6} & \multicolumn{2}{|c|}{5} & \multicolumn{2}{|c|}{4} & \multicolumn{2}{|c|}{3} & \multicolumn{2}{|c|}{2} & \multicolumn{2}{|r|}{1} \\
\hline & & & & $f$ & $\%$ & $f$ & $\%$ & $f$ & $\%$ & $f$ & $\%$ & $f$ & $\%$ & $f$ & $\%$ & $f$ & $\%$ \\
\hline Cazip-Cazip Değil & 30 & 3.2 & 2.0 & 2 & 6.7 & 2 & 6.7 & 5 & 16.7 & 7 & 23.3 & 2 & 6.7 & - & - & 12 & 40.0 \\
\hline Etkileyici-Sıradan & 30 & 3.0 & 1.7 & 2 & 6.7 & 2 & 6.7 & 2 & 6.7 & 4 & 13.3 & 6 & 20.0 & 5 & 16.7 & 9 & 20.0 \\
\hline $\begin{array}{l}\text { Birçok anlamı var-Hiçbir an- } \\
\text { lamı yok }\end{array}$ & 30 & 3.4 & 1.7 & 2 & 6.7 & - & - & 6 & 20.0 & 6 & 20.0 & 7 & 23.3 & 4 & 13.3 & 5 & 16.7 \\
\hline Heyecan verici-Heyecansız & 30 & 4.0 & 1.9 & 3 & 10.0 & 4 & 13.3 & 2 & 6.7 & 12 & 40.0 & 2 & 6.7 & - & - & 7 & 23.3 \\
\hline İlginç-Sıkıcı & 30 & 3.2 & 1.9 & 3 & 10.0 & 2 & 6.7 & - & - & 11 & 36.7 & 2 & 6.7 & 2 & 6.7 & 10 & 33.3 \\
\hline
\end{tabular}

Tablo 3 incelendiğinde okul öncesi öğretmenlerinin mühendislik alanına yönelik anlamsal algıları incelendiğinde belirlenen aritmetik ortalama değerlerine göre matematik alanına yönelik anlamsal algılarından cazip-cazip değil semantik ifadesi için ( $\bar{X}=3.2$; SS:2.0), etkileyici-sıradan semantik ifadesi için ( $\bar{X}=3.0$; SS: 1.7), birçok anlamı var-hiçbir anlamı yok semantik ifadesi için ( $\bar{X}=3.4$; SS: 1.7), heyecan verici-heyecansız semantik ifadesi için ( $\bar{X}=4.0 ;$ SS: 1.9), ilginç-sıkıcı semantik ifadesi için ( $\bar{X}=3.2 ;$ SS: 1.9) olduğu görülmektedir. Buna göre aritmetik ortalama değerlerinden anlaşılacağı üzere okul öncesi öğretmenlerinin mühendislik alanını en çok heyecan verici olarak ve birçok anlamı var olarak algılamaktadır.

Okul öncesi öğretmenlerinin STEM semantik farklılık ölçeğinin teknoloji alanına yönelik anlamsal algıları Tablo 4'de yer almaktadır.

Tablo 4. Okul Öncesi Öğretmenlerinin Teknoloji Alanına Yönelik Anlamsal Algıları

\section{Teknoloji Alanı}

\begin{tabular}{|c|c|c|c|c|c|c|c|c|c|c|c|c|c|c|c|c|c|}
\hline \multirow{3}{*}{ Semantik ifadeler } & \multirow{3}{*}{$\mathbf{N}$} & \multirow{3}{*}{$\bar{x}$} & \multirow{3}{*}{ SS } & \multicolumn{14}{|c|}{ Semantik ífadelerin Dereceleri } \\
\hline & & & & \multicolumn{2}{|c|}{7} & \multicolumn{2}{|c|}{6} & \multicolumn{2}{|c|}{5} & \multicolumn{2}{|c|}{4} & \multicolumn{2}{|c|}{3} & \multicolumn{2}{|c|}{2} & \multicolumn{2}{|c|}{1} \\
\hline & & & & f & $\%$ & f & $\%$ & f & $\%$ & $f$ & $\%$ & f & $\%$ & f & $\%$ & f & $\%$ \\
\hline Cazip-Cazip Değil & 30 & 6.1 & 1.6 & 19 & 63.3 & 2 & 6.7 & 7 & 23.3 & - & - & - & - & - & - & 2 & 6.7 \\
\hline $\begin{array}{l}\text { Birçok anlamı var-Hiçbir an- } \\
\text { lamı yok- }\end{array}$ & 30 & 6.2 & 1.6 & 21 & 70.0 & 5 & 16.7 & - & - & 2 & 6.7 & - & - & - & - & 2 & 6.7 \\
\hline İlginç-Sıkıcı & 30 & 4.2 & 2.1 & 9 & 20.0 & 9 & 20.0 & 4 & 13.3 & 4 & 13.3 & - & - & 2 & 6.7 & 2 & 6.7 \\
\hline Heyecan verici-Heyecansız & 30 & 5.9 & 1.6 & 12 & 40.0 & 9 & 20.0 & 4 & 13.3 & 3 & 10.0 & - & - & 2 & 6.7 & - & - \\
\hline Etkileyici-Sıradan & 30 & 6.2 & 1.4 & 13 & 43.3 & 7 & 23.3 & 8 & 26.7 & - & - & - & - & 2 & 6.7 & - & - \\
\hline
\end{tabular}

Tablo 4 incelendiğinde okul öncesi öğretmenlerinin teknoloji alanına yönelik anlamsal algıları incelendiğinde belirlenen aritmetik ortalama değerlerine göre matematik alanına yönelik anlamsal algılarından cazip-cazip değil semantik ifadesi için ( $\bar{X}=6.1 ; \mathrm{SS}: 1.6)$, bir çok anlamı var- hiçbir anlamı yok semantik ifadesi için ( $\bar{X}=6.2 ; \mathrm{SS}: 1.6)$, ilginç- sıkıcı semantik ifadesi için ( $\bar{X}=4.2$; SS: 2.1$)$, heyecan verici-heyecansız semantik ifadesi için ( $\bar{X}=5.9 ;$ SS: 1.6), etkileyici-sıradan semantik ifadesi için $(\bar{X}=6.2$; SS: 1.4) olduğu görülmektedir. Buna göre aritmetik ortalama değerlerinden anlaşılacağı 
üzere okul öncesi öğretmenlerinin teknoloji alanını en çok etkileyici olarak ve birçok anlamı var olarak algılamaktadır.

\section{STEM Yaklaşımına Yönelik Kullanılan Görüşme Formundan Elde Edilen Bulgular}

Okul öncesi öğretmenlerinin STEM yaklaşımına yönelik düşüncelerini belirlemek amacıyla araştırmacılar tarafindan geliştirilen ve uzman görüşü alınarak son şekli verilen görüşme formunda açık uçlu (birinci bölüm) ve kapalı uçlu (ikinci bölüm) soruların yer aldığı 2 bölümden oluşmaktadır.

\section{Birinci Bölümden Elde Edilen Bulgular}

Görüşme formunun açık uçlu sorularında öğretmenlere "STEM yaklaşımının ne olduğu" ve "okul öncesi eğitimdeki öneminin ne olabileceği" sorulmuş olup okul öncesi öğretmenlerinden elde edilen bulgular Tablo-5 ve Tablo 6 'da sunulmuştur.

Tablo 5. Okul Öncesi Öğretmenlerinin STEM Yaklaşımı Hakkındaki Görüşleri

\begin{tabular}{ll}
\hline Görüşler & $\mathrm{n}$ \\
\hline Çocukların robotik uygulamalar yapması açısından önemli & 2 \\
olması & 9 \\
Açıklama yok & 2 \\
Çocukların teknolojiyi öğrenmesi açısından önemli olması & 2 \\
Çocukların deney yapmasını sağlaması & 2 \\
Çocuğun bilimi öğrenmesi açısından STEM yaklaşımının & 2 \\
öğretmenlerin uygulamalarında zaten yer alması & 3 \\
STEM yaklaşımı hakkında herhangi bir fikre sahip olmama & 3 \\
Çocukların gelişimi açısından önemli olması & 1 \\
Çocukların yaratıcılığıı desteklemesi & 3 \\
Çocukların eleştirel düşünme becerilerine destek sunması & 1 \\
Çocukların problem çözme becerilerini desteklemesi & 1 \\
Bilimi okul öncesi dönemde kullanmaya destek sunması & 1 \\
Çocukların araştırma becerisini desteklemesi & 2 \\
Çocukların bilimsel süreç becerilerini desteklemesi & 1 \\
\hline
\end{tabular}

Tablo 5'de okul öncesi öğretmenlerinin ( $n=30)$, genel olarak STEM yaklaşımına yönelik görüşleri incelendiğinde öğretmenlerin \%20'sinin ( $n=9)$ STEM yaklaşımına yönelik herhangi bir görüş ifade etmemiş olduğu, \%10'unun $(n=3)$ STEM yaklaşımına yönelik bir bilgisinin olmadığını, \%10'unun $(n=3)$ çocukların yaratıcılığını destekleyici bir yaklaşım olduğunu, \%7'sinin ( $n=2$ ) çocukların robotik uygulamalar yapması açısından önemli olduğunu ve yine \%7'sinin ( $n=2)$ çocukların teknolojiyi öğrenmesi açısından önemli olduğunu, yine \%7'sinin $(n=2)$ çocukların deney yapmasının bir yolu olduğunu, yine \%7'sinin ( $n=2$ ) çocukların araştırma becerisini geliştirdiğini, yine \%7'sinin ( $n=2)$ çocukların legolarla tasarımlar yapmasını desteklemesi olduğunu ifade ettikleri görülmektedir. Okul öncesi öğretmenlerinin ( $n=30)$, STEM yaklaşımını \%3'ü ( $n=1)$ bilimi öğrenme açısından önemli, \%3'ü $(n=1)$ eleştirel düşünme becerisine destek olması açısından önemli, \%3'ü $(n=1)$ problem çözme becerisine destek olması açısından önemli, \%3'ü $(n=1)$ bilimsel süreç becerilerinin gelişimi açısından önemli, \%3'ü $(n=1)$ öğrenmeyi kolaylaştran ve derslerin aktif olarak işlenmesini sağlayan bir yaklaşım olarak düşündükleri görülmektedir.

Okul öncesi öğretmenlerinin STEM yaklaşımına yönelik görüşlerine örnek cevapları şu şekildedir;

"STEM yaklaşımını çocukların teknolojiyi öğrenmesi açısından önemli buluyorum" (K18)

"Çocukların Legolarla kendi tasarımlarını yapmaları, böylelikle yaratıcılıklarının desteklenmesi açısından

STEM yaklaşımı önemlidir". (K25)

"Çocukların robotik uygulamaları öğrenmesidir". (K6)

Tablo 6. Okul Öncesi Öğretmenlerinin STEM Yaklaşımının Okul Öncesi Dönemde Uygulanmasına Yönelik Görüşleri

\begin{tabular}{ll}
\hline Görüşler & $\mathrm{n}$ \\
\hline Çocukların erken yaşlarda bilimle tanışmasını sağlaması & 3 \\
Küçük yaşlarda teknolojiyi kullanmayı bilmenin önemi & 2 \\
Okul öncesi dönemde fen ve matematik öğrenimini des- & 1 \\
teklemesi ileride başarılı çocuk yetişmesine firsat sunması & \\
$\begin{array}{l}\text { Küçük yaşlarda çocuklar için önemli olmaması } \\
\text { Cevap yok }\end{array}$ & 5
\end{tabular}

| Kastamonu Eğitim Dergisi, 27(5), 2019| 


\begin{tabular}{ll}
\hline Görüşler & $\mathrm{n}$ \\
\hline Çocukların erken dönemde yaratıcılığına destek sunması & 4 \\
Kodlamanın erken yaşlarda öğrenilmesinin önemi & 2 \\
$\begin{array}{l}\text { Çocukların oyun oynamasına engel olması } \\
\text { Çocukların bilimsel süreç becerilerinin erken yaşlardan iti- }\end{array}$ & 2 \\
$\begin{array}{l}\text { baren gelişmesine firsat sağlaması } \\
\text { Çocukların okul öncesi dönemde problem çözme becerisi- }\end{array}$ & 4 \\
$\begin{array}{l}\text { ni geliştirmesi } \\
\text { Çocukların fen ve matematiği severek öğrenmesine destek } \\
\text { sunması }\end{array}$ & 2 \\
\hline
\end{tabular}

Tablo 6'da okul öncesi öğretmenlerinin okul öncesi dönemde STEM yaklaşımının uygulanmasına yönelik görüşleri incelendiğinde okul öncesi öğretmenlerinin $(n=30)$, \%17'sinin $(n=5)$ küçük yaşlardaki çocuklar için önemli olmadığını ifade ettikleri, \%13'ünün $(n=4)$ erken dönemde yaratıcılığın gelişimi ve problem çözme becerilerinin gelişimine destek sunması açısında önemli olduğunu ve yine \%13'ünün $(n=4)$ cevap vermediği, \%10'unun $(n=3)$ çocukların erken yaştan itibaren bilimi tanımasını ve sevmesini sağladığını, \%7'sinin $(n=2)$ küçük yaşlarda teknolojiyi öğrenmesi açısından ve kodlamayı öğrenmesi açısından önemli olduğunu ve yine $\% 7$ 'sinin $(n=2)$ küçük yaşlarda çocukların oyun oymamasına engel olduğunu ve aynı zamanda yine \%7'sinin $(n=2)$ çocukların fen ve matematiği severek öğrenmesinin bir yolu olduğunu ifade ettikleri görülmektedir. Okul öncesi öğretmenlerinin $(n=30) \% 3$ 'ünün $(n=1)$ okul öncesi dönemde fen ve matematik öğrenimini desteklemesi ve bu doğrultuda ileride başarılı bir çocuk yetiştirmenin bir yolu olduğunu ifade ettiği ve yine \%3'ünün ( $n=1$ ) çocukların erken dönemden itibaren bilimsel süreç becerisini desteklemesi açısından STEM yaklaşımının önemli olduğunu ifade ettikleri görülmektedir.

Okul öncesi öğretmenlerinin okul öncesi dönemde STEM yaklaşımının uygulanmasına yönelik görüşlerine örnek cevapları şu şekildedir;

"Erken yaşlardan itibaren çocukların oyun oynama zamanını çalmasını doğru bulmuyorum". (K8)

"Çocukların erken yaşlardan itibaren bilimle tanışmasını sağlaması ve fen-matematiği sevmesi açısından önemlidir. Çünkü küçük yaşlarda kazanılan fen ve matematik sevgisi tüm yaşamanı etkileyecektir”. (K13)

"Erken yaşlarda çocuklara uygulanmasını doğru bulmuyorum". (K5)

\section{İkinci Bölümden Elde Edilen Bulgular}

Görüşme formunun kapalı uçlu sorularından oluşan ikinci bölümünde ise okul öncesi öğretmenleri kendilerini; "STEM yaklaşımını uygulamaktan hoşlanma durumuna", "STEM yaklaşımını uygulamayı bilme durumuna", "STEM yakIaşımını uygulamada kendine güvenme durumuna", "STEM yaklaşımı uygulaması için gerekli yöntem ve teknikleri bilme durumuna", "STEM yaklaşımını uygulamak için yeterli bilimsel bilgiye sahip olup olmama durumlarına" göre kesinlikle katılıyorum, katılıyorum, kararsızım, katılmıyorum, kesinlikle katılmıyorum şeklinde değerlendirmiştir. Elde edilen bulgular Şekil 2'de gösterilmektedir.

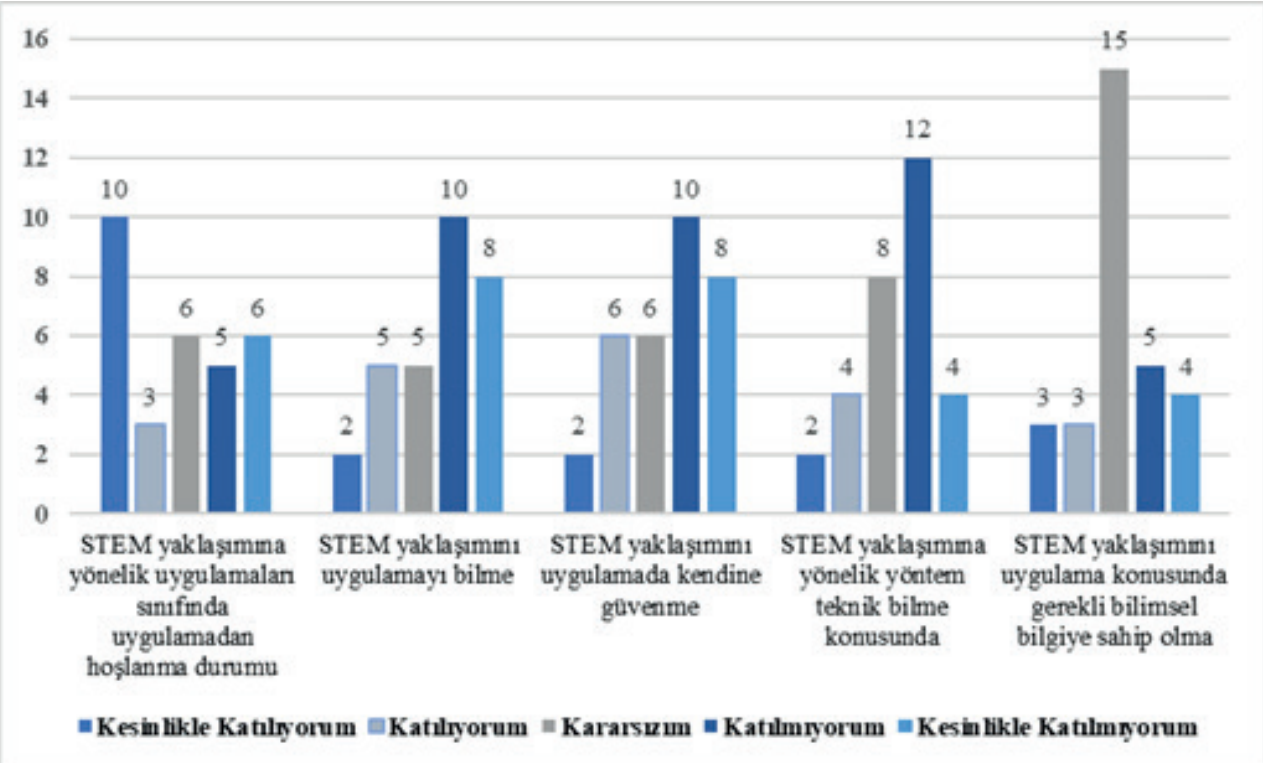

Şekil 2. Okul öncesi öğretmenlerinin STEM yaklaşımına yönelik görüşlere katılma durumları 
Şekil 2 incelendiğinde okul öncesi öğretmenlerinin $(n=30)$, STEM yaklaşımına yönelik uygulamaları sınıfinda uygulamadan hoşlanma konusunda \%33'ünün $(n=10)$ kesinlikle hoşlandığını, \%20'sinin $(n=6)$ bu konuda kararsızlık yaşadığını ve kesinlikle hoşlanmadığını, \%17'sinin ( $n=5)$ uygulamadan hoşlanmadığını ve \%10'unun ( $n=3)$ uygulamadan hoşlandığını ifade ettiği görülmektedir. Okul öncesi öğretmenlerinin ( $n=30)$, STEM yaklaşımını uygulamayı bilme konusunda \%33'ünün ( $n=10)$ bilmediğini, \%27'sinin ( $n=8)$ kesinlikle bilmediğini, \%17'sinin $(n=5)$ bildiğini ve bu konuda kararsız kaldığını, \%7'sinin ( $n=2)$ STEM yaklaşımını uygulamayı kesinlikle bildiğini ifade ettikleri görülmektedir. Okul öncesi öğretmenlerinin ( $n=30)$, STEM yaklaşımını uygulamada kendine güvenme konusunda \%33'ünün $(n=10)$ kendine güvenmediklerini, \%27'sinin ( $n=8)$ kesinlikle güvenmediklerini, \%20'sinin $(n=6)$ kararsız kaldığını ve kendine güvendiklerini, $\% 7$ 'sinin ( $n=2)$ kendisine kesinlikle güvendiğini ifade ettiği görülmektedir. Okul öncesi öğretmenlerinin STEM yaklaşımını uygulamada gerekli olan yöntem ve teknikleri bilme konusunda \%40'ının ( $n=12)$ bilmediklerini, \%27'sinin $(n=8)$ kararsız kaldığını, \%13'ünün ( $n=4)$ kesinlikle bilmediğini ve bildiğini, \%7'sinin ( $n=2)$ kesinlikle bildiğini ifade ettiği görülmektedir. Okul öncesi öğretmenlerinin ( $n=30$ ), STEM yaklaşımını uygulama konusunda gerekli bilimsel bilgiye sahip olma konusunda \%50'sinin ( $n=15)$ kararsız kaldıklarını, \%17'sinin $(n=5)$ bilimsel bilgiye sahip olmadıklarını, \%13'ünün $(n=4)$ kesinlikle bilmediğini, \%10'unun $(n=3)$ yeterli bilimsel bilgiye sahip olma konusuna kesinlikle katıldıklarını ve katıldıklarını ifade ettikleri görülmektedir.

\section{Sonuçlar}

Okul öncesi öğretmenlerinin STEM alanlarına yönelik anlamsal algılarının ve STEM yaklaşımına yönelik düşüncelerinin belirlendiği bu araştırmadan elde edilen bulgular doğrultusunda genel olarak okul öncesi öğretmenlerinin STEM alanlarına (fen alanı, teknoloji alanı, mühendislik alanı, matematik alanı) yönelik anlamsal algılarının olumlu ifadeler içererek çoğunlukla fen alanını ilginç, matematik ve mühendislik alanlarını etkileyici, mühendislik alanını ise heyecan verici buldukları görülmektedir. Ancak okul öncesi öğretmenlerinin STEM yaklaşımına yönelik bilgilerinin yeterli düzeyde olmadığı da görülmektedir. Bunun yanı sıra okul öncesi öğretmenleri erken dönemde eğitim ortamlarında STEM yaklaşımının uygulanmasını çocukların erken dönemde bilimle tanışması, yaratıcılığııın gelişmesine destek sunması ve çocukların problem çözme becerisinin gelişmesine destek sunması açısından önemli bulmaktadır.

Okul öncesi öğretmenlerinin STEM alanlarına yönelik anlamsal algılarını belirlemek amacıyla kullanılan STEM Semantik Farklılık Ölçeği'nden elde edilen bulgular doğrultusunda okul öncesi öğretmenlerinin fen alanına yönelik olumlu tutumlara sahip oldukları ve fen alanı için en çok kendileri için birçok anlamının olduğunu ( $\bar{X}=6.3, S S: 1.08)$ ve kendileri için ilginç ( $\bar{X}=5.9$; SS: 1.14) olduğunu düşünmektedirler. Alan yazında okul öncesi öğretmenlerinin fen alanına yönelik düşüncelerinin belirlendiği birçok araştırma mevcuttur. Bu araştırtmalarda okul öncesi öğretmenlerinin fene karşı olumsuz tutumlara sahip olduğu sonucu yaygın olarak görülse de (Kuru ve Akman, 2017; Sağlam ve Aral, 2015; Gelman ve Brenneman, 2012; Hamlin ve Wisneski, 2012; Greenfield, Jirout, Dominguez, Greenberg, Maier ve Fuccillo, 2009; Yoon ve Onchwari, 2006; Metz, 2009) bazı araştırmalarda okul öncesi öğretmenlerinin fen alanına karşı olumlu tutumda oldukları ancak uygulama sürecinde okul öncesi dönemdeki çocuklarla nasıl uygulama yapacaklarını bilemediklerine yönelik sonuçlar da mevcut bulunmaktadır (Timur, 2012; Fayez, Sabah ve Oliemat, 2011; Erden ve Sönmez, 2011; Kıldan Pektaş, 2009; Uysal, 2007; Eshach, 2003). Bu sonuçlarda da okul öncesi öğretmenlerinin genel olarak fene karşı olumlu tutuma ve algıya sahip olmaları bu araştirma sonucunu da desteklemektedir.

Okul öncesi öğretmenlerinin matematik alanına yönelik anlamsal algıları incelendiğinde matematik alanını kendileri için etkileyici ( $\bar{X}=5.7$; SS: 1.6) ve kendileri için cazip ( $\bar{X}=5.5$; SS: 1.3) olarak algıladıklarını ifade ettikleri görülmektedir. Bu sonuç Li, Liu, DeBey, McFadden, ve Pan (2018); Anders ve Rossbach (2015); Lee ve Ginsburg (2007); Tarım ve Bulut (2006); Umay (2003) tarafindan yapılan araştırma sonuçları ile desteklenmektedir. Bu araştırma sonuçlarında da okul öncesi öğretmenlerinin matematik alanına yönelik görüşlerinin olumlu tutumlar içerdiği görülmektedir.

Okul öncesi öğretmenlerinin mühendislik alanına yönelik anlamsal algıları incelendiğinde mühendislik alanını kendileri için heyecan verici ( $\bar{X}=4.0$; SS: 1.9) ve kendileri için birçok anlamı olduğunu ( $\bar{X}=3.4 ;$ SS: 1.7) ifade ettikleri görülmektedir. Alan yazında okul öncesi öğretmenlerinin mühendislik alanına yönelik algılarının incelendiği bir araştırmaya ulaşılamamıştr. Ancak Lachapelle, Cunningham, ve Davis (2018) tarafindan yapılan araştırmanın hedef kitlesi ilköğretim çağındaki çocuklar olsa da dolaylı olarak öğretmenlerin mühendislik alanına yönelik eğitim almalarının alt çizilmektedir.

Okul öncesi öğretmenlerinin teknoloji alanına yönelik anlamsal algıları incelendiğinde teknoloji alanını kendileri için etkileyici ( $\bar{X}=6.2$; SS: 1.4$)$ ve kendileri için birçok anlamı olduğu ( $\bar{X}=6.2 ;$ SS: 1.6) yönünde olumlu ifadelerinin olduğu görülmektedir. Alan yazında Yılmaz, Tomris ve Kurt, (2016); Yurt ve Kalburan, (2011); Sandberg, (2002) tarafindan yapılan araştırmalarda da okul öncesi öğretmenlerinin okul öncesi dönemde teknoloji kullanımının önemli olduğunu ifade etmeleri bu araştirma sonucunu da desteklemektedir. 
Okul öncesi öğretmenlerinin STEM yaklaşımına yönelik görüşleri incelendiğinde ise öğretmenlerin genel olarak STEM yaklaşımına yönelik bilgisinin olmadığı ve görüş ifade etmekten kaçındıkları görülmektedir. Görüş bildiren okul öncesi öğretmenlerinin ise STEM yaklaşımının genel olarak robotik uygulamalardan oluştuğunu, çocuklarda yaratıcılığı ve teknoloji öğrenimini desteklediğini, çocuklarda deney yapmanın bir yolu olduğunu, bilimsel süreç becerilerinin gelişimine destek sunduğunu, legolarla tasarımlar yapılmasına firsat sunduğunu ifade ettikleri ayrıca çocukların 21. yüzyıl becerilerinden problem çözme becerisine, eleştirel düşünme becerisine destek sunduğunu da ifade ettikleri görülmektedir. Görüldüğü gibi okul öncesi öğretmenlerinin genel olarak STEM yaklaşımı hakkında bilgi sahibi olmasalar da görüş bildiren okul öncesi öğretmenlerinin STEM yaklaşımını sadece robotik uygulamalar ve legolarla tasarım yapma gibi eksik ve yanlış düşünceler olarak görmesi Günşen, Bayır ve Fazlıoğlu, (2018) tarafindan yapılan araştırma ile de desteklenmektedir. Günşen vd.'nin (2018) yapmış oldukları araştrmada da okul öncesi öğretmenlerinin büyük çoğunluğu STEM yaklaşımını robotik kodlamalar ve legolarla tasarımlar yapmak olarak düşünmektedir. Okul öncesi öğretmenlerinin STEM yaklaşımının okul öncesi dönemde uygulanmasına yönelik görüşleri incelendiğinde ise okul öncesi öğretmenlerinin büyük çoğunluğunun erken dönemlerde çocuklar için önemli olmadığını buna gerekçe olarak da çocukların oyun oynama zamanını çaldığını düşünmekte oldukları görülmektedir. Oysa ki alan yazında birçok araştırma erken dönemlerde STEM yaklaşımına yönelik yapılan eğitimsel uygulamaların çocukların ileride bilime yönelik olumlu tutumlar geliştirmelerine katkı sağladığını ortaya koymaktadır (Allen, 2016; Torres-Crospe, Kraatz ve Pallansch, 2014; Moomaw ve Davis, 2010). STEM yaklaşımının erken dönemlerde uygulanmasına yönelik olumlu bakış açısına sahip okul öncesi öğretmenleri ise STEM yaklaşımının çocuklarda yaratıcılık, problem çözme becerisi gibi 21. Yüzyıl becerilerine vurgu yaparak bu becerilerin gelişimine destek sunduğunu ifade etmiş olup bu sonuçlar Uğraş (2017) tarafindan yapılan çalışma sonuçları ile de paralellik göstermektedir.

Okul öncesi öğretmenlerinin STEM (fen, teknoloji, mühendislik ve matematik) alanlarına yönelik semantik algılarının büyük çoğunluğunun olumlu ifadeler içermiş olmasına rağmen, STEM yaklaşımının erken yaşlardan itibaren uygulanmasına yönelik olumsuz görüşlere sahip olmaları genel olarak STEM yaklaşımına ve uygulamalarına yönelik doğru bilgiye sahip olmadıklarına ve bu konuda kendilerine güvenmediklerini ifade etmiş olmalarına bağlanabilir. Ayrıca okul öncesi öğretmenlerinin STEM yaklaşımını bilmediklerini ve kendilerine uygulamada güvenmediklerini ifade etmiş olmalarına rağmen çoğunluğunun sınıfinda uygulamaktan hoşlanabileceğini ifade etmiş olmaları da zihinlerinde var olan STEM alanlarına yönelik olumlu semantik algılara ve ülkemiz eğitiminde oldukça gündemde olan bir yaklaşım olmasına bağlanabilir. Bu sonuçlar okul öncesi öğretmenlerine STEM yaklaşımına yönelik verilecek eğitimlerin sayısının arttırılarak onların STEM yaklaşımına yönelik doğru bilgi edinmelerine ve güven duygularının gelişimine destek sunarak okul öncesi dönemde STEM yaklaşımına yönelik kaliteli sınıf içi uygulamaların da sayısının artmasına destek sunabilir.

\section{Araştırmanın Sınırlılıkları}

Bu araştırmada okul öncesi öğretmenlerinin STEM alanlarına yönelik semantik algıları fen bilgisi öğretmenliği ve ilköğretim matematik öğretmenliği adayları üzerinde uyarlama çalışması yapılmış olan STEM Semantik Farklılık Ölçeği ile belirlenmiş olup bu durum araştırmanın sınırlılığını oluşturmaktadır.

\section{6. Öneriler}

Günümüz çocuklarının gelecekte yaşam mücadelesi verip yeni buluşlar geliştirebilmesinin yolu STEM (Fen, Teknoloji, Mühendislik, Matematik) eğitiminden geçmektedir. Araştırmalar önümüzdeki 10 yıl içerisinde mesleklerin \% $80^{\prime}$ inde STEM becerileri konusunda derin bir anlayışa ihtiyaç duyulacağını ifade etmektedir. Bu nedenle günümüzde okul öncesi dönemden itibaren STEM eğitimi uygulanmaya başlanmalı ve bunun için gerekli öğretmen eğitimlerinin yaygınlaştrılarak ve uygun öğrenme ortamları düzenlenerek fen, matematik, mühendislik ve teknoloji eğitimi çocuklara sorgulayıcı şekilde verilmelidir. Ayrıca ülkemizde güncellemesi yeni yapılan öğretmen yetiştirme lisans programlarında okul öncesi öğretmenliği programı incelendiğinde önceden 2 farklı dönemde okutulan fen ve matematik eğitimi derslerinin aynı döneme getirilmesi de her 2 alanının okul öncesi öğretmenliği öğretmen adayları tarafindan entegrasyonunu kolaylaştırmakla birlikte STEM yaklaşımının ders olarak okutulabilmesine de firsat sunabilecektir. Bununla birlikte zorunlu veya seçmeli şekilde STEM yaklaşımının ve uygulamalarının yer aldığı derslerin de lisans programına eklenmesi 21. yüzyıl gereksinimlerine uygun öğretmen ve çocuk yetiştirmek adına günümüzde bir zorunluluk olduğu düşünülmektedir. Ayrıca araştırmanın sınırılığını oluşturan STEM Semantik Farklıık Ölı̧eği'nin uyarlama çalışması okul öncesi öğretmenleri üzerinde yapılarak alan yazına katkı sunulabilir.

\section{Kaynakça}

Akdağ, F. T. \& Güneş, T. (2015). Enerji konusunda yapılan STEM uygulamaları ile ilgili Fen Lisesi öğrenci ve öğretmen görüşleri. International Journal of Social Sciences and Education Research, 3(5 S), 1643-1656. 
Aladé, F., Lauricella, A. R., Beaudoin-Ryan, L. \& Wartella, E. (2016). Measuring with Murray: Touchscreen technology and preschoolers' STEM learning. Computers in Human Behavior, 62, 433-441.

Akgündüz, D. \& Akpınar, B.C. (2018). Okul öncesi eğitiminde fen eğitimi temelinde gerçekleştirilen STEM uygulamalarının öğrenci, öğretmen ve veli açısından değerlendirilmesi. Yaşadıkça Eğitim, 32 (1).

Akgündüz, D., Aydeniz, M., Çakmakçı, G., Çavaş, B., Çorlu, M. S., Öner, T., \& Özdemir, S. (2015). STEM eğitimi türkiye raporu. İstanbul: Scala Basım.

Akgündüz, D. \& Özçelik, A. (2018). Üstün/Özel Yetenekli Öğrencilerle Yapılan Okul Dışı STEM Eğitiminin Değerlendirilmesi1. Journal of Education, 8(2).

Aldemir, J. \& Kermani, H. (2016). Integrated STEM curriculum: improving educational outcomes for head start children. Early Child Development and Care (ISSN: 0300-4430 (Print) 1476-8275 (Online) Journal homepage: http://www.tandfonline.com/ loi/gecd20).

Allen, A. (2016). Don't ferar STEM-You already teach it. School age/after school Exchance, September/October 56-59.

Anders, Y. \& Rossbach, H. G. (2015). Preschool teachers' sensitivity to mathematics in children's play: The influence of math-related school experiences, emotional attitudes, and pedagogical beliefs. Journal of Research in Childhood Education, 29(3), 305-322

Aronin, S. \& Floyd, K. K. (2013). Using an iPad in inclusive preschool classrooms to introduce STEM concepts. Teaching Exceptional Children, 45(4), 34-39.

Awad, N. \& Barak, M. (2018). Pre-service Science Teachers Learn a Science, Technology, Engineering and Mathematics (STEM)-Oriented Program: The Case of Sound, Waves and Communication Systems. Eurasia Journal of Mathematics, Science and Technology Education, 14(4), 1431-1451.

Becker, K. \& Park, K. (2011). Effects of integrative approaches among science, technology, engineering, and mathematics (STEM) subjects on students' learning: A preliminary meta-analysis. Journal of STEM Education: Innovations and Research, 12(5/6), 23.

Beymer, P. N., Rosenberg, J. M., Schmidt, J. A. \& Naftzger, N. J. (2018). Examining relationships among choice, affect, and engagement in summer STEM programs. Journal of Youth and Adolescence, 1-14.

Brenneman, K. (2011). Assessment for preschool science learning and learning environments. Early Childhood Research \& Practice, $13(1), \mathrm{n} 1$.

Bybee, R. W. (2010). Advancing STEM education: A 2020 vision. Technology and engineering teacher, $70(1), 30$.

Büyüköztürk, Ş. (2012). Bilimsel Araştırma Yöntemleri (18. Baski). Ankara: Pegem Akademi Yayımcılık.

Chesloff, J. D. (2013). STEM education must start in early childhood. Education Week, 32(23), 27-32.

Corlu, M. S., Capraro, R. M., \& Capraro, M. M. (2014). Introducing STEM education: implications for educating our teachers for the age of innovation. Egitim ve Bilim, 39(171).

Clements, D. H. \& Sarama, J. (2016). Math, science and technology in the early grades. The Future of Children, 26(2), 75-90.

Creswell, J.W. \& Plano Clark, V.L. (2015). Karma yöntem araştırmaları. (Çeviri Litap). Anı Yayıncılık, 2. Baskı. Ankara.

Çevik, M. (2018). Impacts of the project based (PBL) science, technology, engineering and mathematics (STEM) education on academic achievement and career interests of vocational high school students. Pegem Eğitim ve Öğretim Dergisi, 8(2), 281-306.

Ensari, Ö. (2017). Öğretmen adaylarının FETEMM eğitimi ve FETEMM etkinlikleri hakkındaki görüşleri (yayınlanmamış yüksek lisans tezi). Yüzüncü Yıl Üniversitesi Eğitim Bilimleri Enstitüsü Matematik ve Fen Bilimleri Eğitimi Anabilim Dalı Fizik Eğitimi Bilim Dalı, Van.

Erden, F.T. \& Sönmez, S. (2011). "Study of Turkish preschool teachers' attitudes toward science teaching". International Journal of Science Education, 33(8), 1149-1168, 201.

Eshach, H. (2003). Inquiry-events as a tool for changing science teaching efficacy belief of kindergarten and elementary school teachers. Journal of Science Education and Technology, 12(4), 495-501.

Fayez, M., Sabah, S.A. \& Oliemat, E. "Jordanian early childhood teachers' perspectives toward science teaching and learning". International Research in Early Childhood Education, 2(1), 76-95, 2011.

Furtak, E. M., Seidel, T., Iverson, H., \& Briggs, D. C. (2012). Experimental and quasi-experimental studies of inquiry-based science teaching: A meta-analysis. Review of Educational Research, 82(3), 300-329. doi:10.3102/0034654312457206.

Gelman, R. \& Brenneman, K. (2012). Classrooms as learning labs. In N. Stein ve S. Raudenbusch (Eds.), Developmental science goes to school. New York, NY: Routledge. 706, 113-126.

Gerde, H., Pierce,S., Lee, K. \& Van Egeren, L. (2018). Early Childhood Educators' Self-Efficacy in Science, Math, and Literacy Instruction and Science Practice in the Classroom. Early Education and Development Vol. 29, Iss. 1.

Gonzales, M. \& Freyer, C. (2014). A collaborative initiative: STEM and universlly designed curriculum for at-risk prescholers. Natioanal Teacher Education Journal, 7(3), 21-29.

Gökbayrak, S. \& Karışan, D. (2017). Investigating the effect of STEM based laboratory activities on preservice science teacher's STEM awareness STEM temelli laboratuvar etkinliklerinin fen bilgisi öğretmen adaylarının STEM farkındalıklarına etkisinin incelenmesi. Journal of Human Sciences, 14(4), 4275-4288. 
Greenfield, D. B., Jirout, J., Dominguez, X., Greenberg, A., Maier, M., \& Fuccillo, J. (2009). Science in the preschool classroom: A programmatic research agenda to improve science readiness. Early Education and Development, 20, 238-264.

Günşen, G. \& Uyanık Balat, G. (2017). Okul Öncesi Dönemde STEM Yaklaşımı. Okul Öncesi Dönemde Fen Eğitimi içinde (s.137-156). Ed. Berrin Akman, Gülden Uyanık Balat, Tülin Güler Yıldız. Anı Yayıncılık, Ankara.

Gürbüz, S. \& Şahin, F. (2016). Araştırma evreni ve örnekleme, Sosyal Bilimlerde Araştırma Yöntemleri Felsefe-Yöntem-Analiz (123144). Seçkin Yayın Evi, Ankara.

Hamlin, M., \& Wisneski, D. B. (2012). Supporting the scientific thinking and inquiry of toddlers and preschoolers through play. Young Children, 67, 82-88.

Hobbs, L., Clark, J. C. \& Plant, B. (2018). Successful Students-STEM Program: Teacher Learning Through a Multifaceted Vision for STEM Education. In STEM Education in the Junior Secondary (pp. 133-168). Springer, Singapore.

Johnson, R. B., Onwuegbuzie, A. J. \& Turner, L. A. (2007). Toward a definition of mixed methods research. Journal of mixed methods research, 1(2), 112-133.

Katz, L. (2010, May). STEM in the early years. Paper presented at the SEED 2010: STEM in early education and development conference. Retrieved from http://ecrp.uiuc.edu/bevond/seed/.

Knezek, G. \& Christensen, R. (2008). STEM semantics survey. Erişim: 21.12.2016, http://iittl.unt.edu/sites/default/files/STEMSemanticssurvey.pdf

Kızılay, E. (2017). STEM semantik farklılık ölçeği'nin Türkçe'ye uyarlanması. International Journal of Social Science. 58 , p. $131-144$.

Kildan, O. \& Pektaş, M. (2009). Erken çocukluk döneminde fen ve doğa ile ilgili konuların öğretilmesinde okulöncesi öğretmenlerinin görüşlerinin belirlenmesi. Ahi Evran Üniversitesi Kırşehir Eğitim Fakültesi Dergisi, 10(1).

Kuru, N., \& Akman, B. (2017). Okul öncesi dönem çocuklarının bilimsel süreç becerilerinin öğretmen ve çocuk değişkenleri açısından incelenmesi. Eğitim ve Bilim, 42(190), 269- 279.

Lachapelle, C. P., Cunningham, C. M., \& Davis, M. E. (2018). Middle Childhood Education: Engineering Concepts, Practices, and Trajectories. Handbook of Technology Education, 141.

Lee, J. S. \& Ginsburg, H. P., 2007. What is appropriate mathematics education for fouryear-olds? Journal of Early Childhood Research, 5,1, $2-31$.

Leuchter, M., Saalbach, H., \& Hardy, I. (2014). Designing science learning in the first years of schooling. An intervention study with sequenced learning materials on the topic of 'floating and sinking'. International Journal of Science Education, 36(10), 17511771. doi:10.1080/09500693.2013.878482.

Li, X., Liu, S., DeBey, M., McFadden, K. \& Pan, Y. J. (2018). Investigating Chinese preschool teachers' beliefs in mathematics teaching from a cross-cultural perspective. Early Years, 38(1), 86-101.

Miles, M. B. \& Huberman, A. M. (1994). Qualitative data analysis: An expanded sourcebook (2nd ed.). Thousand Oaks, CA: Sage. Milford, T. \& Tippett, c. (2016). International Research in Early Childhood Education Vol. 6, No. 1, 2015 , page 24.

Moomaw, S. \& Davis, J. A. (2010). STEM comes to preschool. Young Children, 65(5), 12-18.

National Research Council (NRC). (2011). Successful K-12 STEM education: Identifying effective approaches in science, technology, engineering and mathematics. Washington, DC: The National Academic Press.

Park, M., Dimitrow, D. M., Patterson, L. G. \& Park, D.Y (2017). Early childhood teachers' beliefs about readiness for teaching science, technology, engineering, and mathematics. Journal of Early Childhood Research 2017, Vol. 15(3) 275-291.

Pekbay, C. (2017). Fen teknoloji mühendislik ve matematik etkinliklerinin ortaokul öğrencileri üzerindeki etkileri (yayınlanmamış doktora tezi) Hacettepe Üniversitesi Eğitim Bilimleri Enstitüsü, Ankara.

Safiee, N., Jusoh, Z. M., Noor, A. M. H. M., Tek, O. E. \& Salleh, S. M. (2018, January). An early start to STEM education among year 1 primary students through project-based inquiry learning in the context of a magnet. In IOP Conference Series: Materials Science and Engineering (Vol. 296, No. 1, p. 012023). IOP Publishing.

Sağlam, M. \& Aral, N. (2015). Okul öncesi öğretmenlerin fen etkinlikleri hakkındaki görüşlerinin belirlenmesi. Inönü Üniversitesi Eğitim Fakültesi Dergisi, 16(3), 87-102.

Sandberg, A. (2002). Preschool teacher's conceptionsof computers and play. Information Technology in Childhood Education Annual, 1, 245-263.

Schreier, M. (2014). Qualitative content analysis. In U. Flick (Ed.), The SAGE Handbook of Qualitative Data Analysis. London: SAGE.

Selvi, M. \& Yıldırım, B. (2017). STEM öğretme-öğrenme modelleri: 5E öğrenme modeli, proje tabanlı öğrenme ve STEM sos modeli. Pegem Atf indeksi, 203-236.

Sullivan, A., \& Bers, M. U. (2016). Robotics in the early childhood classroom: learning outcomes from an 8-week robotics curriculum in pre-kindergarten through second grade. International Journal of Technology and Design Education, 26(1), 3-20.

Şencan, H. (2005). Sosyal ve davranışsal ölçümlerde güvenilirlik ve geçerlilik. Seçkin Yayıncılık.

Tarım, K., \& Bulut, M. S. (2006). Okulöncesi öğretmenlerinin matematik ve matematik öğretimine ilişkin algı ve tutumları. Çukurova Üniversitesi Eğitim Fakültesi Dergisi, 2(32), 152-164. 
Torres-Crospe, M. N., Kraatz, K. \& Pallansch, L. (2014). From feraring STEM to playing with it: The natural integration of STEM into the preschool clasroom. SRATE Journal, 23(2), 8-16.

Trundle, K., \& Saçkes, M. (2012). Science and early education. In R. Pianta (Ed.), Handbook of early childhood education (pp. 240258). New York, NY: Guilford.

Uğraş, M. (2017). Okul öncesi öğretmenlerinin STEM uygulamalarına yönelik görüşleri. Eğitimde Yeni Yaklaşımlar Dergisi, 1(1), 39-54.

Umay, A. (2003). Okul öncesi öğretmen adaylarının matematik öğretmeye ne kadar hazır olduklarına ilişkin bazı ipuçları. Hacettepe Üniversitesi Eğitim Fakültesi Dergisi, 25(25).

Uyanık Balat, G. \& Günşen, G., (2017). Okul Öncesi Dönemde STEM Yaklaşımı. Akademik Sosyal Araştırmalar Dergisi. Yıl: 5, Sayı: 42, s. 337-348.

Uysal, H., Tepetaş Cengiz, Ş., Güçhan Özgül, S., Akar Gençer, A. \& Akman, B. (2016). Okul öncesi öğretmenlerinin bilim defterlerine ilişkin görüşlerinin incelenmesi. Necatibey Eğitim Fakültesi Elektronik Fen ve Matematik Eğitimi Dergisi, 10(1), 85-106.

Wang, H. H., Moore, T. J., Roehrig, G. H., \& Park, M. S. (2011). STEM integration: Teacher perceptions and practice. Journal of Pre-College Engineering Education Research (J-PEER), 1(2), 2.

Yıldırım, A. \& Şimşek, H. (2003). Sosyal bilimlerde nitel araştırma yöntemleri. Ankara: Seçkin Yayınları

Yılmaz, E., Tomris, G. \& Kurt, A.A. (2016). Okul öncesi öğretmenlerinin özyeterlik inançları ve teknolojik araç-gereç kullanımına yönelik tutumları: Balıkesir ili örneği. Anadolu Journal of Educational Sciences International, 6(1), 1-26.

Yoon, J., \& Onchwari, J. A. (2006). Teaching young children science: Three key points. Early Childhood Education Journal, 33, 419-423.

Yurt, Ö. \& Kalburan, N.C. (2011). Early childhood teachers' thoughts and practices about the use of computers in early childhood education. Procedia Computer Science 3, 1562-1570. 